\title{
THE RELATIONSHIP BETWEEN \\ FAITH AND REASON \\ IN JOHANNINE THEOLOGY: \\ A BIBLICAL AFFIRMATION OF PRESUPPOSITIONAL APOLOGETICS
}

\author{
Peter A. Lillback \\ Westminster Theological Seminary, Philadelphia, USA
}

\begin{abstract}
ABSTRAK: Melalui kajian dari perspektif biblikal-teologis, yakni melalui penelahaan terhadap teologi Yohanes, penulis menyelesaikan kontroversi klasik antara iman dan akal. Pertanyaan utamanya adalah apakah proposisi-proposisi wahyu bersifat dapat diketahui hanya karena Allah telah membicarakannya atau bahwa manusia juga boleh menemukan proposisi-proposisi wahyu itu itu melalui pencarian filosofis. Melalui kajian terhadap teologi Yohanes, penulis mengafirmasikan signifikansi apologetika presuposisional.
\end{abstract}

KATA KUNCI: Iman, rasio, Yohanes, apologetika presuposisi.

ABSTRACT: Through a study from biblical-theological perspective, that is a study of Johannine theology, the writer reconciles a classical controversy between faith and reason. The main question is whether the revelational propositions are discoverable only because God has spoken it or that man may also find those revelational propositions 
through a philosophical exploration. Through the study of Johannine theology, the writer affirmed the significance of presuppositional apologetic.

KEYWORDS: Faith, reason, Johannine, presuppositional apologetics.

One of the abiding theological and philosophical themes through the Christian centuries has been the relationship between faith and reason. Clark Pinnock writes,

The relationship between faith and reason has been a hot subject for discussion throughout the Christian era. Opinions have ranged along a continuum from extreme fideism which affirms the exclusive sufficiency of faith all the way over to extreme rationalism which comes close to identifying religion and philosophy. ${ }^{1}$

K. Scott Oliphint puts it this way,

"Reasons of Faith" - the two terms themselves (so far, "of" has remained relatively free from the fires of controversy) spark passions and debates, from past to present, that cause contenders quickly to choose sides and to profess allegiances. The reaction is due, in part, to the subject matter under scrutiny when these words appear together. ${ }^{2}$

The reason for this unceasing dialogue among Christian thinkers is traceable to their commitment to divine revelation. W. T. Jones writes,

\footnotetext{
1 Clark Pinnock, "Faith and Reason," Bibliotheca Sacra 131, no. 523 (October-December 1974): 303.

2 K. Scott Oliphint, Reasons for Faith: Philosophy in the service of Theology (Phillipsburg: P\&R, 2006), 3.
} 
The faith-reason controversy, on the other hand, is peculiar to Christian philosophy and arises only because the Christian philosopher accepts the authority of revelation. The classical mind, for its part, rested on no special revelation; what it knew it had discovered through its own efforts. ${ }^{3}$

As Jones's remark implies, "faith" here refers to the special revelation accepted by the Christian as certain truth because of its source in God. "Reason," on the other hand, is the attempt of the mind and human experience alone to decide whether the claims of revelation are true or false.

Nevertheless, Jones's observation masks a profound reality recognized by many Christian epistemologists and apologists that a great measure of unwarranted faith is unwittingly exercised by all philosophers. ${ }^{4}$ Preeminent among apologists who have argued in this manner is the Westminster Theological Seminary Professor, Cornelius Van Til. Consider this claim made by Van Til,

If one does not make human knowledge wholly dependent upon the original self-knowledge and consequent revelation of God to man, then man will have to seek knowledge within himself as the final reference point. Then he will have to seek an exhaustive understanding of reality. Then he will have to hold that if he cannot attain to such an exhaustive understanding of

3 W. T. Jones, A History of Western Philosophy: The Medieval Mind (2nd ed.; New York: Harcourt Brace Jovanovich, 1969), 197.

4 "The view that faith underlies all rationality holds that rationality is dependent on faith for its coherence. Under this view, there is no way to comprehensively prove that we are actually seeing what we appear to be seeing, that what we remember actually happened, or that the laws of logic and mathematics are actually real. Instead, all beliefs depend for their coherence on faith in our senses, memory, and reason, because the foundations of rationalism cannot be proven by evidence or reason." "Faith and Rationality." Online:

http://en.wikipedia.org/wiki/Faith_and_rationality; accessed: 04/08/2014 
reality, he has no true knowledge of anything at all. Either man must then know everything or he knows nothing. This is the dilemma that confronts every form of non-Christian epistemology. ${ }^{5}$

Analysts of Van Til's apologetic, such as Greg Bahnsen and John Frame have described this as "the transcendental argument for God's existence." ${ }^{\prime 6}$ Michael R. Butler explains the transcendental argument as follows,

Cornelius Van Til revolutionized Christian apologetics in the twentieth century. His system of the defense of the faith rejected the common practice among Christian apologists of assuming a neutral, autonomous point of view when confronting unbelief. In its place he urged a presuppositional, theonomic approach of establishing the truth of Christian theism. He maintained that because God, speaking in his word, is the ultimate epistemological starting point, there is no way of arguing for the faith on the basis of something other than the faith itself. God's authority is ultimate and thus selfattesting. To argue for the faith on any other authority is to assume there is a higher authority than God himself to which he must give account. But the very attempt to do this is self-defeating. Consequently, the Christian apologist must stand upon God's authoritative word and presuppose its truth when contending for the faith. This stand does not relegate the apologist to fideism. Indeed, the very opposite is the case. Upon the rock foundation of God's word the Christian is able to demonstrate the foolishness of unbelieving thought while at the same time vindicate the greatness

5 Cornelius Van Til, A Christian Theory of Knowledge (Nutley: P \& R, 1975), 17 (italics in original).

6 See, for example, Greg L. Bahnsen, Van Til's Apologetic: Readings and Analysis (Phillipsburg: P\&R, 1998), 496-529; John M. Frame, Cornelius Van Til: An Analysis of His Thought (Phillipsburg: P\&R, 1995), 275-79, 311-22. For a popular treatment of Van Til's thought, see Richard L. Pratt Jr., Every Thought Captive: A Study Manual for the Defense of Christian Truth (Phillipsburg: P \& R, 1979). 
of divine wisdom.7

Thus presuppositional apologetics asserts that faith is a transcendentally necessary precondition to reason. This means that without faith one cannot make sense of the laws that govern reasoning. Indeed, the very concept of "proof" presupposes faith. Accordingly, there is nothing more rational than faith in God. Van Til puts it this way:

The Reformed method of apologetics seeks to escape this nemesis. It begins frankly "from above." It would "presuppose" God. But in presupposing God it cannot place itself at any point on a neutral basis with the non-Christian. Before seeking to prove that Christianity is in accord with reason and in accord with fact it would ask what is meant by "reason" and what is meant by "fact." It would argue that unless reason and fact are themselves interpreted in terms of God they are unintelligible. If God is not presupposed, reason is a pure abstraction that has no contact with fact, and fact is pure abstraction that has no contact with reason. Reason and fact cannot be brought into fruitful union with one another except upon the presupposition of the existence of God and his control over the universe. ${ }^{8}$

Auguste Lecerf agrees and declares,

Let us engage in polemics; let us rush to attack the vain maxims of socalled autonomous reason; let us tear from the gnosis its false mask of Christian; let us make human wisdom blush for its folly and human religion for its impiety. But, once for all, let us refrain from constituting reason the judge of revelation and thus the judge of God

\footnotetext{
7 Michael R. Butler, “The Transcendental Argument for God's Existence." Online: http://butler-harris.org/tag/; accessed: 04/08/2014.

8 Van Til, A Christian Theory of Knowledge, 18.
} 
Himself. ${ }^{9}$

Jones, however, makes a point. The classic controversy between faith and reason can be summarized by the question: Are the propositions of revelation knowable only because God has spoken, or may man also discover them through philosophical inquiry? This is what this study addresses. The approach here, however, is not historical, philosophical, or a systematic theological perspective. Instead, we consider the matter from a biblical-theological perspective, namely, from the vantage point of Johannine theology.

Answering this question in this way is not to say that we should ignore philosophical and apologetic efforts. We ought not to diminish the importance of the historical, philosophical or systematic theological viewpoints for this debate. While John did not deal with these questions in a systematic matter, they are issues that are informed by his Gospel. Accordingly some representative thinkers from the traditional debate will be considered.

An outline of the leading understandings of the relationship between faith and reason in historic Christian discussions of apologetics may be helpful here. ${ }^{10}$ Bernard Ramm offers three primary systems of Christian apologetics:

\footnotetext{
9 Auguste Lecerf, An Introduction to Reformed Dogmatics (1949; repr., Grand Rapids: Baker, 1981), 203-4.

10 Three helpful surveys of various approaches to Christian apologetics are: Gordon R. Lewis, Testing Christianity's Truth Claims: Approaches to Christian Apologetics (Chicago: Moody, 1976); Doug Powell, Holman Quick Source Guide to Christian Apologetics (Nashville, Tenn.: Holman Reference, 2006); Bernard Ramm, Varieties of Christian Apologetics: An Introduction to the Christian Philosophy of Religion (rev. ed.; Twin Brooks Series; Grand Rapids: Baker, 1974).
} 
Systems Stressing Subjective Immediacy-Blaise Pascal, Søren Kierkegaard, Emil Brunner

Systems Stressing Natural Theology - Thomas Aquinas, Joseph Butler, F. R. Tennant

Systems Stressing Revelation-Augustine, John Calvin, Abraham Kuyper $^{11}$

To the first category, we might add the earlier historic Christian scholars, Tertullian, from the Ancient Church era and Bernard of Clairvaux, from the Medieval Church period. To the second category we might add the more recent names of John Gerstner and Josh McDowell. ${ }^{12}$ Van Til is best identified with the third category. ${ }^{13}$

John's purpose, however, was not that of a Kierkegaard, an Aquinas, or an Augustine in regard to the relation of faith to reason. These apologists considered the question of faith and reason by attempting to address the problem directly. Their approaches emerged from interaction with the gospel and opposing world and life views. John, on the other hand, as an inspired author of Scripture, had the specific task of presenting the gospel itself. Nevertheless, he spoke with force regarding the relation of faith and reason, even if it was in a subsidiary way and not with the specific design of the fore-

\footnotetext{
11 Bernard Ramm, Varieties of Christian Apologetics, 9.

12 A Christian rationalist approach is represented by John H. Gerstner, Reasons for Faith (Twin Brooks Series; Grand Rapids: Baker, 1967) and the evidentialist method is employed by Josh McDowell, ed., More Evidence That Demand a Verdict: Historical Evidences for the Christian Scriptures (rev. ed.; San Bernardino: Here's Life, 1981).

13 In fact, in an earlier version of his book, Ramm dealt with Van Til instead of Calvin along with apologists stressing revelation; see Bernard Ramm, Types of Apologetic Systems: An Introductory Study to the Christian Philosophy of Religion (Wheaton, Ill.: Van Kampen, 1953), 184209.
} 
mentioned apologists.

The claim asserted here is that these apologists' insights while helpful, should only be espoused if they are in harmony with Holy Scripture itself, in this case, Johannine theology. To that end, consideration will be given to four primary areas. The first is the Johannine vocabulary that touches upon faith and reason. The second is the structure of the Fourth Gospel as it begins with the prologue and then proceeds to trace the growth of belief and unbelief. The third is the Johannine emphasis on the divine initiative in salvation joined with the doctrine of human inability to believe and the significance of these doctrines for the faith-reason controversy. The fourth is John's concept of truth and the Holy Spirit's witness.

The vast amount of relevant material means only a small portion can be discussed here. So our primary focus will be on the Fourth Gospel. The other Johannine writings are referred to occasionally.

\section{The Contribution of the Johannine Vocabulary to the Faith- Reason Controversy}

John's view of the relationship of faith and reason can be observed in part by his use of terminology. The Johannine vocabulary presents a propensity toward contrasts or antonyms. George E. Ladd speaks of this as the Johannine dualism.

The dualism of John is primarily vertical: a contrast between two worlds-the world above and the world below. "You are from 
below, I am from above; you are of this world, I am not of the world" (Jn. 8:23).14

We are not to think of this as an ultimate or metaphysical dualism however. ${ }^{15}$ Edwin K. Lee writes,

John conceives very vividly the contrast between the divine nature and the created world. As God is light, and in the light, so is the world characterized as darkness. But, though the contrast is strongly marked, it has no point of contact with metaphysical dualism. Indeed, Irenaeus says that the main purpose of the Gospel was to refute such Gnostic teaching. ${ }^{16}$

\section{Indeed, Johannine theology has been described as presuppositional in} character. ${ }^{17}$ In the prologue of John we learn that all things were

14 George E. Ladd, A Theology of the New Testament (rev. ed.; Grand Rapids.: Eerdmans, 1993), 259. See also John Ashton, Understanding the Fourth Gospel (2nd ed.; New York: Oxford University Press, 2007), 387-417; Robert Kysar, John: The Maverick Gospel (rev. ed.; Louisville, Ky.: Westminster/John Knox Press, 1993), 58-77; Judith Lieu, The Theology of the Johannine Epistles (New Testament Theology; New York: Cambridge University Press, 1991), 80-87; I. Howard Marshall, New Testament Theology: Many Witnesses, One Gospel (Downers Grove: InterVarsity, 2004), 511; D. Moody Smith, The Theology of the Gospel of John (New Testament Theology; New York: Cambridge University Press, 1995), 16-17.

15 See, for example, Christina Urban, Das Menschenbild nach dem Johannesevangelium: Grundlagen johanneischer Anthropologie (WUNT 2, 137; Tübingen: J. C. B. Mohr [Paul Siebeck], 2001), 82-86.

16 Edwin K. Lee, The Religious Thought of St. John (London: S.P.C.K, 1950), 109. Lee refers here to Irenaeus's Againt Heresies 3.11.1 (ANF 1:426). For more on Irenaeus (120-202/3), see William Edgar and K. Scott Oliphint, eds., Christian Apologetics Past and Present: A Primary Source Reader (2 vols.; Wheaton, Ill.: Crossway, 2009, 2011), 1:83-114, and L. Russ Bush, Classical Readings in Christian Apologetics, A.D. 100-1800 (Grand Rapids: Zondervan, 1983), 63-82.

17 Smith states, “Johannine theology presupposes God, scripture, Jesus, tradition about him, and a distinctly Christian understanding of who he was. There is a sense in which all these factors are axiomatic for the fourth evangelist. In addition, there are a couple of presuppositions that are probably not best understood simply as theological axioms, or at least they have other dimensions. ... the Gospel of John presupposes a distinctively Christian community, a church, that stands over against the synagogue, having in all likelihood emerged from it... This Christian community is not, however, defined only or primarily by its opposition to Judaism, or 
created by the Word (John 1:3). Matter is not intrinsically evil, rather it has become evil. That matter is not of itself evil is seen in the Word who created matter and also became matter in the incarnation (John 1:14). Evil is not an eternal entity but has had a temporal dualism of which John speaks. Let us consider some of the terms in the Johannine dualism that make a significant contribution toward an understanding of John's view of the relationship of faith and reason. Our first set of terms is "above" and "below." This speaks of the two different worlds in John's vertical dualism. In addition to John 8:23, several other verses can be cited which continue the contrast of "above" (heaven, to God) and "below" (this world): "No one has ascended into heaven but he who descended from heaven" (John 3:13 NASB); "I came down from heaven, not to do mine own will but the will of him that sent me" (John 6:38 KJV); "What if ye shall see the Son of man ascend up where he was before?" (John 6:62 KJV); "I am ascending to my Father and your Father, to my God and your God" (John 20:17 ESV); "If any man walk in the day, he stumbleth not, because he seeth the light of this world" (John 11:9 KJV); and "of judgment, because the prince of this world is judged" (John 16:11 $\mathrm{KJV})$.

To this contrast can be added the terms "light" and "darkness." The heavenly sphere is the realm of light, while the earthly sphere of

even by its beliefs. It is a community in which the Spirit continues the presence and ministry of Jesus (20:22; 14:16-17). The vitality of the Spirit, as well as the church's reliance upon the Spirit, was a hallmark of Johannine Christianity ..." (Smith, The Theology of the Gospel of John, 79). 
"this world" is the realm of darkness. ${ }^{18}$ Some passages that illustrate this dualism are: "And the light shineth in darkness; and the darkness comprehendeth it not" (John 1:5 KJV); “Then spake Jesus again unto them, saying, I am the light of the world: he that followeth me shall not walk in darkness, but shall have the light of life" (John 8:12 KJV); "As long as I am in the world, I am the light of the world" (John 9:5 $\mathrm{KJV}) ;$ "Then Jesus said unto them, Yet a little while is the light with you. Walk while ye have the light, lest darkness come upon you: for he that walketh in darkness knoweth not whither he goeth. While ye have light, believe in the light, that ye may be the children of light." (John 12:35-36 KJV). Ladd summarizes this dualism as follows:

Those who receive the light become the children of light (12:36). However, in spite of the fact that the light has come into the world, people loved darkness rather than light and refused to come to the light because their deeds were evil. Whoever "does the truth" comes to the light that his or her true nature may be disclosed (3:19-20). In John the crowning evil is hatred of the light-unbelief in Jesus. ${ }^{19}$

The significance of Johannine dualism for the faith and reason controversy should already be coming clear. If mankind is in darkness and so hates the light, how can there be a neutral discussion through reason which will cause a man to set aside his bias and come to faith? Can we argue from logic (as in the ontological argument) or from the existence and order of nature (the cosmological and

18 See Peder Borgen, "Logos Was the True Light," in David E. Orton, ed., The Composition of John's Gospel: Selected Studies from Novum Testamentum (Brill's Readers in Biblical Studies 2; Leiden: Brill, 1999), 107-22.

19 Ladd, A Theology of the New Testament, 260. 
teleological arguments) to the God of light with a man who basic disposition is to deny such a God? Van Til explains the impossibility of such an apologetical method,

No proof for this God and for the truth of his revelation in Scripture can be offered by an appeal to anything in human experience that has not itself received its light from the God whose existence and whose revelation it is supposed to prove. One cannot prove the usefulness of the light of the sun for the purposes of seeing by turning to the darkness of a cave. The darkness of the cave must itself be lit up by the shining of the sun. When the cave is thus lit up, each of the objects that are in it "proves" the existence and character of the sun by receiving their light and intelligibility from it. ${ }^{20}$

Van Til's point is that every proof a Christian would use to prove God must already presuppose God. For if the God of the Bible (the God John has said created all things in 1:3) exists, then every thing that is already speaks of God for it was made by Him. The creature always presupposes the priority of the Creator. How can a proof start with a creature and move to God? If it is a creature it already necessarily demands the existence of the Creator. The God John speaks of can never be a conclusion of an argument, for without this God no argument could even begin! But Van Til is saying more. He says that darkness can never prove light. This is because darkness is the absence of light. The natural man in John's dualism is in the darkness of the cave. In fact, he is said not only to hate the light, but also to be

20 Cornelius Van Til, The Defense of the Faith (4th ed.; ed. K. Scott Oliphint; Phillipsburg: P\&R Publishing, 2008), 109. Van Til alludes to Plato's Allegory of the Cave found in book 7 of his Republic; see Plato, Republic 7:514-17 (LCL 276 [2013], 106-19). 
unable to even see the light for he is blind. Jesus says in John 9:39-41 $(\mathrm{KJV})$,

For judgment I am come into this world, that they which see not, might see; and that they which see might be made blind. And some of the Pharisees which were with him heard these words, and said unto him, Are we blind also? And Jesus said unto them, If ye were blind, ye should have no sin: but now ye say, We see; therefore, your sin remaineth.

From this we infer that in John's mind it is impossible to ever argue successfully for God's existence. A man who hates the light, who cannot even see the light, will never discuss neutrally the existence of such a God of light. Either he will hate the light or be unable to even see any glimmer of truth for he cannot perceive light with blinded eyes. It would seem further that John would be opposed to any effort to reason for God. This would seem evident in the term 'light' itself. Merrill C. Tenney writes,

In conclusion, this witness of which John speaks is selfauthenticating. The Prologue uses the figure of light, and calls Jesus "the light of the world," a metaphor which He used in controversy with His enemies. "I," He said, "am the light of the world: he who follows Me shall not walk in the darkness, but shall have the light of life." The instant reaction of the Pharisees was, "You are bearing witness of Yourself; Your witness is not true" (John 8:12-13). Light, however, needs no authentication; it validates itself. Nobody needs to label or to describe light; it speaks for itself. In the same way the reality of Christ makes its impact on human life and verifies His claims by the transformation that it produces on all that He affects. The risen Christ is His own best witness, and He confirms the 
subordinate witnesses that support His claims. ${ }^{21}$

To clarify Tenney's point, one might think of a test by a scientist to prove the existence of light. He would see the necessary pieces to assemble his apparatus. He would read the results of his test. Regardless of his conclusion respecting light's existence, he had in his experiment already assumed light's existence. How did he see his apparatus, or read his conclusions? - by light, of course. Light cannot be proved, and in a similar way spiritual truth cannot be proved, but is rather assumed or taken by faith.

Other antonyms are used by John as well: 'flesh' and 'spirit' (John 3:6), children of God and children of the devil (John 8:39-44), etc. Rather than expounding each and every contrast, allow this summary by Lee to suffice,

At first sight the world appears as something wholly evil. Without Christ it is darkness and not light $(1.9 ; 8.12)$. It has refused to know the Word, its creator (1.10). Its ruler is the Devil, and it appears to tolerate his rule with equanimity, so that both together are destined to suffer the same fate $(12.31 ; 16.11 ; 1$ Jn. 5.19). Everything that is in the world, being lust of the flesh and lust of the eyes, is of the world and not of God (1 John 2.16). The world has given birth to false prophets; they speak of the world and the world heareth them (1 John 4.3-5). Christ cannot or will not pray for it (17.9); and its hatred is focused on him (7.7; 15.18), and his disciples (15.18; 17.14; 1 John 3.13). Though Christians are bidden to love one another, they are commanded not to love the world: "If any man love the world, the love of the Father is not in him" (1 John 2.15). The business of the Christian appears to be

21 Merrill C. Tenney, “Topics from the Gospel of John. Part III: The Meaning of 'Witness' in John," Bibliotheca Sacra 132, no. 527 (July-September 1975): 241. 
not to save the world, but to overcome the world (1 John 5.4, 5). ${ }^{22}$

If our analysis of the implications of the Johannine dualism is correct (that faith or presuppositions rather than reason lead to God), then we ought to expect little or no use of terms by John that suggests the Thomistic approach of "reason and faith." ${ }^{23}$ In its place, we should expect to find terms that would either support the Augustinian approach of "faith and reason" 24 or the "faith without reason" 25

22 Lee, The Religious Thought of St. John, 110-11.

23 Thomistic philosophy is named after St. Thomas Aquinas (1224-74). He is the leading Catholic theologian. In the Middle Ages, he synthesized the newly found Aristotle with Catholic dogma as it then stood. The key emphasis as one might expect from Aristotle's philosophy would be the sufficiency of human reason to prove spiritual truth (Christian and Catholic faith). In Aquinas's system whatever could be proven was no longer a matter of faith, but of knowledge by reason. He therefore sought to prove all he could about the Christian faith. He is famous for his cosmological argument for the existence of God. Frederick Coplestone, the Catholic philosopher and historian, admits that Aquinas is the key link in the history of thought that permitted the independence of philosophy from under the domain of theology; cf.

Frederick Coplestone, A History of Philosophy, Volume II, Mediaeval Philosophy, Augustine to Scotus (Westminster, Md.: Newman, 1950), 310. For more on Thomas Aquinas's apologetics, see Edgar and Oliphint, eds., Christian Apologetics Past and Present, 1:395-407, and Bush, Classical Readings in Christian Apologetics, 271-300.

24 Augustine (354-430) is a bishop of the early church immediately following the sacking of Rome. His main contribution was to develop a systematic philosophy of Christianity. He saw the necessity of beginning with revelation, and then following from truths of revelation of developing a philosophy. His main stress was "I believe in order to understand." He taught clearly the sovereignty of God in salvation, the necessity of divine revelation, and human depravity and inability in all spiritual realms. He is the fountainhead for the reformation thinkers. For more detail about his views on apologetics, see Edgar and Oliphint, eds., Christian Apologetics Past and Present: A Primary Source Reader, 1: 205-307, and Bush, Classical Readings in Christian Apologetics, 195-236, and subsequent references to Augustine in this article.

25 Tertullian (ca. 160-ca. 225) was an early church apologist. He was of the Montanist sect, and so leaned heavily on mysticism. As a result, he denied the possibility of any Christian philosophy. One simply believed Christianity and enjoyed it, he did not worry if Christianity was rational, because he knew it was true experientially. His position is described as "faith without reason." For more detail about Tertulian's views, see Edgar and Oliphint, eds., Christian Apologetics Past and Present: A Primary Source Reader, 1:115-56, and Bush, Classical Readings in Christian Apologetics, 83-95. 
approach of Tertullian. This would mean that John should lay great stress on faith, and little on arguments. If he stresses evidences at all, they should be subordinate to the presupposition of God's necessary existence. To see if we are correct, let us now see what words John makes use of to teach the value of reason and the value of faith.

One of the first discoveries one makes after reading through the Fourth Gospel searching for John's use of such words as "reason," "mind," "persuade" is that John either does not use them, or does it very infrequently. The closest we come to the word for "reason" in

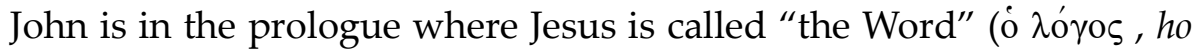
logos, or, "reason"). ${ }^{26}$ Here Christ is the "Logic of God." ${ }^{27}$ Obviously, reason here is not man's, but it is the infinitely rational God in his self-revelation. "Persuade" is used once in 1 John 3:19 (KJV), "And hereby we know that we are of the truth, and shall assure [persuade] our hearts before him." This use is not the act of persuading an unbeliever by reason to trust in the God of Holy Scripture, but rather a believer gaining assurance of his own genuine state of conversion. The closest we come to "mind" in John is in 1 John 5:20 (KJV), "And we know that the Son of God is come, and hath given us an understanding, that we may know him that is true; and we are in him that is true, even in his Son Jesus Christ. This is the true God, and

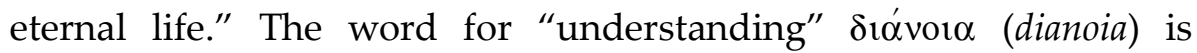

\footnotetext{
26 For a discussion of Philo's and John's use of the Logos concept, see Harold W. Attridge, "Philo and John: Two Riffs on One Logos," in Essays on John and Hebrews (WUNT 264; Tübingen: Mohr Siebeck, 2010), 46-59.

27 See Gordon Clark's The Johannine Logos (Nutley: P \& R, 1972).
} 
similar to the Greek word for "mind" (vov̂s, nous). Yet this understanding is obviously not the result of a lengthy philosophical dialectic. It is said to be "given us" by the Son of God.

To begin, John asserts that Jesus possessed knowledge that Jesus's hearers did not possess. Jesus's hearers stood in a state of ignorance with respect to Jesus's origin and his destination, "Jesus answered, 'Even if I do bear witness about myself, my testimony is true, for I know where I came from and where I am going, but you do not know where I come from or where I am going. You judge according to the flesh . .'"' (8:14-15 ESV). The unbelievers addressed

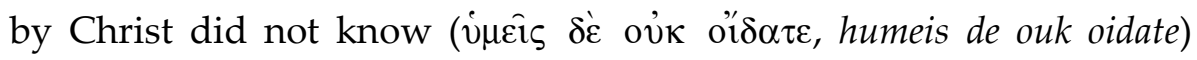
while Jesus did know where he had come from and where he was

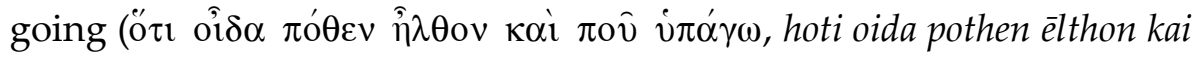

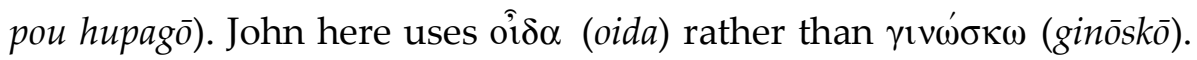
The emphasis of oi $\delta \alpha$ (oida) generally tends to be more conceptual than experiential, which is more the provenance of $\gamma \imath v \omega \sigma \kappa \omega$ (ginōskō). ${ }^{28}$ In John's mind, there does not seem to be an equivalence of conceptual knowledge shared between Jesus and his unbelieving contestants. This is consistent with what seems to be a consistent emphasis by Johannine theology that there is not an epistemological common ground of thinking shared by the believer and the unbeliever. This, of course, is a foundational concern of

28 For more on this terminology, see Seeseman," oi $\delta \alpha^{\prime \prime}$, in TDNT 5:116-19, esp. 118-10 and"oi $\delta \alpha^{\prime \prime}$ BDAG 693-94. 
presuppositional or covenantal apologetics. ${ }^{29}$

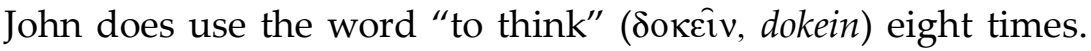
The amazing thing is that in all eight cases, the protagonists are thinking incorrectly, or ignorantly. John is clearly showing that human thought cannot be trusted. In 5:39, Jesus tells the Jews that their thinking of finding eternal life in the searching of the Scriptures as an act in itself is not sufficient for salvation. In 5:45, He tells them that they ought not to think that Jesus will be the one to accuse them, for Moses will, not Jesus. In 11:13, the disciples thought incorrectly that Lazarus was sleeping for rest instead of sleeping in death. In 11:31, the Jews comforting Mary after Lazarus's death thought she ran to the tomb instead of to Jesus. In 11:56 the Jews plotting for Jesus were thinking with uncertainty whether Jesus would come to the feast. In 13:29, the disciples thought that Jesus had told Judas to go from the table to buy food or give to the poor, instead of to betray him. In 16:2, Jesus says that the time was coming when people would kill the disciples thinking that they were serving God. In 20:15, Mary thought Jesus was the gardener and not the risen Lord. So we see on every hand that John's stress on dualism because of sin between God and man is held to consistently when it comes to the human ability to think his way to God. This is clearly a serious blow to Thomistic

29 Cf. K. Scott Oliphint, Reasons for Faith, 146-66; idem, Covenantal Apologetics: Principles and Practice in Defense of Our Faith (Phillipsburg: P\&R, 2013), 151-60; Richard B. Gaffin Jr., "Epistemological Reflections on 1 Corinthians 2:6-16," and Jeffrey K. Jue, "Theologia Naturalis: A Reformed Tradition," in Revelation and Reason: New Essays in Reformed Apologetics, ed. K. Scott Oliphint and Lane G. Tipton (Phillipsburg: P\&R, 2007), 24, 169. 
philosophy. The "reason" of man is not to be considered as the ultimate. Is our expectation of great stress on faith in Johannine thought to prove correct? The answer is an overwhelming 'yes.'

We must now analyze John's use of "faith." 30 In so doing, we will be seeking to define "faith" as well as to see whether the view of faith and reason espoused by Augustine or the one of Tertullian is truly consistent with Scripture. ${ }^{31}$

When we begin to study the term "faith" in John, we make a surprising discovery. John almost never uses the noun ( $\pi_{i} \mathbf{\sigma} \tau 1 \varsigma$, pistis)

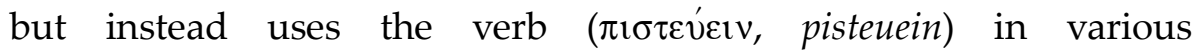
constructions nearly one hundred times. Howard writes,

This noun is never used in the Gospel, or in the Second or Third Epistles. Only once do we meet with it in the First Epistle: "This is the victory that has conquered the world, our faith" [1 John 5:4]. Over against this must be set the striking fact that the word ( $\pi \iota \tau \varepsilon v \varepsilon \varepsilon v$ [pisteuein]), "to believe," "to exercise faith," occurs nearly one hundred times in the Gospel and nine times in the First Epistle. ${ }^{32}$

This seems to have been a deliberate avoidance of the noun on the part of John. The best suggestion to explain this phenomenon has been offered by Howard,

\footnotetext{
30 See Rudolf Schnackenburg, The Gospel According to St John (trans. Kevin Smyth; 3 vols.; New York: Herder and Herder, 1968), I:558-75.

31 Augustine and Tertullian do not differ on the priority of faith over reason. They do differ in that Augustine believed that reason was possible for the Christian after faith, while Tertullian said that any effort to prove Christianity after faith was unnecessary. It was simply to be believed because it was impossible to the unsaved man and internally certain to the believer. 32 W. F. Howard, Christianity According to St. John (London: Duckworth, 1943), 154-55.
} 
It seems more likely that the tendency in post-Pauline Christian use, to think of faith as a fixed deposit of truth, led St. John to prefer the verb. This stands for the active exercise of the higher judgement, with a certain moral force, in so far as it involves the taking up of a personal attitude toward Christ. ${ }^{33}$

Ladd's comment is helpful as well,

"The best solution for John's avoidance of the noun in favor of the verb is that he wished to avoid the possibility that faith would be understood merely as correct theology". ${ }^{34}$

As mentioned earlier, John uses $\pi \imath \sigma \tau \varepsilon v ́ \omega$ (pisteuō) in various ways. Tenney lists eight different New Testament usages, seven of which

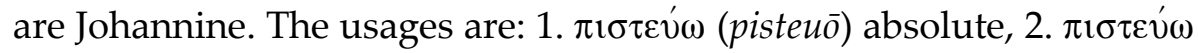
(pisteuō) followed by the preposition عis (eis), 3. $\pi \imath \sigma \tau \varepsilon v ́ \omega$ (pisteuō) with the accusative case in the sense of "entrust," $4 \pi \imath \sigma \varepsilon v \dot{\omega} \omega$ (pisteuō) again with the accusative referring to a principle or fact accepted as credible, 5. $\pi$ $\sigma \tau \varepsilon v ́ \omega$ (pisteuō) followed by an object clause introduced

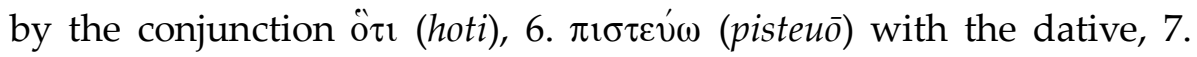
$\pi \imath \sigma \varepsilon v^{\prime} \omega\left(\right.$ pisteuō) with the preposition $\varepsilon^{\varepsilon} v(e n) .{ }^{35} \mathrm{C}$. H. Dodd has shown that these usages have a source in Hebraic thinking.

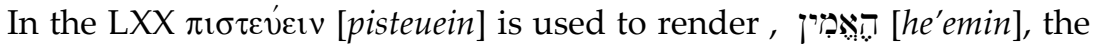
Hiphil of , אמןj ['mn], a root which conveys... the idea of firmness or stability. The Hiphil means 'to stand firm'. With the prepositions $ל[l]$ and $z[b]$ it signifies to stand firm by virtue of one's relation to a person

\footnotetext{
33 Howard, Christianity According to St. John, 155.

34 Ladd, A Theology of the New Testament, 307, n. 4.

35 Merrill C. Tenney, "Topics from the Gospel of John. Part IV: The Growth of Belief," Bibliotheca Sacra, 132, no. 528 (October-December 1975): 343-44.
} 
(or object), and so rely firmly upon him (or it), i.e. to trust or credit a person. It thus approximates to the sense of $\pi \imath \sigma \varepsilon v \varepsilon \imath v$ [pisteuein] with the dative, and in fact this construction is almost invariably used in the LXX.... Further, [מאמין [he'emin] develops the sense of 'to be firmly convinced', and so can be used with a '-clause [ki-clause]. This is a fairly exact equivalent of $\pi \imath \sigma \varepsilon v i \varepsilon ı$ [pisteuein], but is rather rare in the Old Testament. ${ }^{36}$

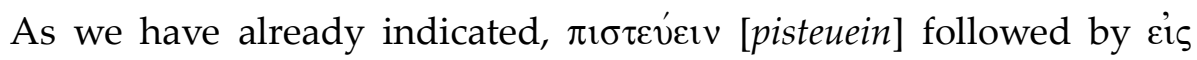
[eis] is a very clear usage of John. The interesting fact about this usage is that it has no extra-Biblical Greek parallel. Dodd explains,

We now come to a form of expression for which there is no parallel, so far as I can discover, either in profane Greek or in the LXX: $\pi \imath \sigma \tau \varepsilon v i \varepsilon v$ [pisteuein] followed by kis [eis] with the accusative. This would appear to be an alternative way of representing the Hebrew As an equivalent for the Hebrew preposition cis [eis] is quite natural. It would seem that $\pi 1 \sigma \tau \varepsilon v i \varepsilon \imath$ [pisteuein] with the dative so inevitably connoted simple credence, in the sense of an intellectual judgment, that the moral element of personal trust or reliance inherent in the Hebrew and Aramaic phrase-an element integral to the primitive Christian conception of faith in Christ-needed to be otherwise expressed. ${ }^{37}$

From these facts, we should be able to see that John was concerned about faith as it is in a person's life and not just as it is written in a book in the sense of a creed. He wanted to avoid the misconception that faith was only having certain propositions in the mind, but it was rather a person whose total being was committed to Christ.

\footnotetext{
36 C. H. Dodd, The Interpretation of the Fourth Gospel (New York: Cambridge University Press, 1953), 180-81.

37 Dodd, The Interpretation of the Fourth Gospel, 183.
} 
At this, we have come to a crucial problem for the relationship between faith and reason in our own day. If reason cannot bring us to God (which as we have seen above is Johannine theology), and John seems to here downplay the value of the mind in salvation, are we not left to sheer emotional commitment in our definition of faith? Might this not warrant the existentialist irrationality that is often linked with Søren Kierkegaard (1813-55)? ${ }^{38}$ Is not then the liberal crisis theology with its existentialist emphases often associated with Karl Barth (1886-1968) placed on valid exegetical grounds? ${ }^{39}$

This perspective of liberal theology is clarified by Van A. Harvey's analysis of the implications of Luther's rejection of the Roman Catholic view of faith. The Catholic view of faith, jettisoned by Luther, taught that intellectual assent needs the added works of love to be enough for salvation. Harvey explains,

38 For Kierkegaard's apologetics, see Edgar and Oliphint, eds., Christian Apologetics: Past and Present, 2:313-30, and Ramm, Varieties of Christian Apologetics, 49-65. For selections of Kierkegaard's writings, see Howard V. Hong and Edna H. Hong, eds., The Essential Kierkegaard (Princeton University Press, 2000), and Robert Bretall, A Kierkegaard Anthology (New York: Modern Library, 1946). For short introductions to Kierkegaard's thought, see Hendrikus Berkhof, Two Hundred Years of Theology: Report of a Personal Journey (trans. John Vriend; Grand Rapids: Eerdmans, 1987), 71-81; Edmund P. Clowney, "A Critical Estimate of Søren Kierkergaard's Notion of the Individual," Westminster Theological Journal 5, no. 1 (November 1942): 29-61; and S. U. Zuidema, Kierkegaard (trans. David H. Freeman; Philadelphia: P \& R, 1960).

39 For introductions to Barth and his writings, see David L. Mueller, Karl Barth (Makers of the Modern Theological Mind; Waco, Tex.: Word, 1972); Rolf J. Erler and Reiner Marquard, eds., A Karl Barth Reader (ed. and trans. Geoffrey W. Bromiley; Grand Rapids: Eerdmans, 1986); and Berkhof, Two Hundred Years of Theology, 179-207. For a Reformed evaluation of Barth, see Cornelius Van Til, Christianity and Barthianism (1962; repr., Phillipsburg: P\&R, 2004), and Harvie M. Conn, Contemporary World Theology: A Layman's Guidebook (Nutley: P \& R, 1973), 10-23. For the relationship between Barth and evangelical theology which includes discussions of Van Til's critique of Barth, see Bruce L. McCormack and Clifford B. Anderson, eds., Karl Barth and American Evangelicalism (Grand Rapids: Eerdmans, 2011). 
Luther rejected the limitation of faith to assent and regarded it as the response of the total person in trust to the graciousness of God as it was revealed in Jesus Christ. Since faith was regarded as total and trustful reliance on God's faithfulness, it includes hope and charity. Faith is the basic inclination of the heart or will. It followed that the object of faith was not supernatural truth but God himself, his trustworthiness. Thus, Luther frequently contrasted believing a doctrine of the INCARNATION with trusting in the benefits of Christ's coming. Although Luther himself accepted orthodox doctrine, the logic of his position led to the view that doctrine was but an attempt to express faith, and not itself the object of faith. This, in turn, led to the more radical conclusion drawn by later Protestants that orthodox doctrine was but a relative and historically conditioned attempt to give utterance to faith in the mercy of God. Since orthodox formulations are relative to one era, they might, in other epochs, stand in the way of a true understanding and faith. 40

In our own day, this sort of thinking has brought the liberal theology to another view of faith. Packer explains,

But then there is the very different account of faith given by radical Protestants which runs like this: Faith related to a Jesus who, in Schaeffer's sense and our sense of the word, is not there. His status is precisely this $-\mathrm{He}$ is a community memory. As one expositor of this school put it, He is, mark the phrase, a "perspectival image in the church's consciousness." ${ }^{41}$

This explanation of faith grows out of a union of psychology and theology. The crucial point is not what or who one believes, but that one believes. Packer explains that this is due to

\footnotetext{
40 Van A. Harvey, A Handbook of Theological Terms (New York: Macmillan, 1964), 96-97.

41 James I. Packer, “The Way of Salvation. Part II: What Is Faith?” Bibliotheca Sacra 129, no. 516 (October-December 1972), 298.
} 
...the bad nineteenth and twentieth century habit of psychologizing the structures of faith. That is worth pausing over for a moment, because we need to recognize that it is not only Christian faith which psychologically involves the elements of knowledge and assent and trust. It is equally true of Buddhist faith and Marxist faith, if it is the psychological structure of faith that you are interested in. The twentieth century, alas, is much more interested in the psychological structures of faith than in the difference between the objects of faith in the different systems. It is this preoccupation with the psychological structures of faith which has contributed to the situation in which two radically different accounts of faith can be given and the greater part of the Christian world hardly be aware of what is happening. ${ }^{42}$

Could this possibly be what John is advocating? It is sure that John is desirous of true personal commitment as $\pi \imath \tau \varepsilon v i \varepsilon ı$ (pisteuein) indicates, but does his stress on personal commitment and the inability of sinful man to reason to God make him an irrationalist theologically? Does John teach faith in faith regardless of content as liberal theology has? The answer here is clearly 'no.' Luther's perceived emphasis on commitment at the expense of truth in doctrine may well have had an ill effect on orthodoxy. But did Luther fully capture the Biblical emphasis of Johannine theology? Lee's remark concerning John's view of faith is pertinent here, "Belief in all its various forms is never regarded as an end or ultimate object. There is not thought of 'believing in believing.'" 43

This becomes quite obvious when two of John's usages of

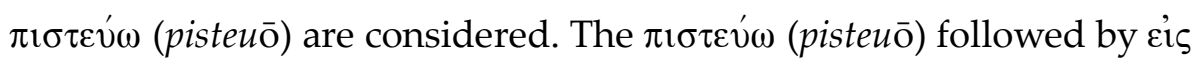

\footnotetext{
42 Packer, “The Way of Salvation," 300.

43 Lee, The Religious Thought of St. John, 226.
} 
(eis) usage is clearly crucial for this point in that it almost always has 'Jesus' as its object. Tenney writes,

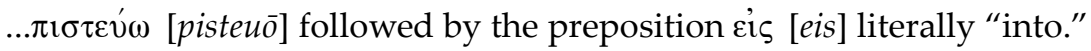
It appears thirty-seven times in the Gospel of John, more often than in any other Gospel. It implies a definite committal to a person, usually the person of Christ...44

Howard agrees,

The object of faith in the Johannine, as in the Pauline, message is nearly always Jesus. This is one of the cardinal claims of the Fourth Gospel, for Jesus is represented as the Logos, the spoken word of God, who has been sent forth from God to reveal the divine Character. 45

Yet this usage in itself does not allow us to escape the liberal concept of faith "in a Jesus who is not there." The way to demonstrate that Jesus is not "the church's collective consciousness" is through the consideration of the $\pi \_\tau \tau \varepsilon \dot{\varepsilon v v ~(p i s t e u e i n) ~ f o l l o w e d ~ b y ~ o ̈ ~} \tau \imath$ (hoti) usage. This usage shows that certain propositions must be true about the person who is the object of our belief. In other words, personal trust is into a person who actually has certain characteristics. Dodd explains,

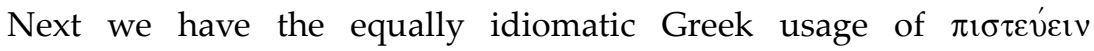
[pisteuein] with a ö $\tau$-clause [hoti-clause]. . . The content of belief is in

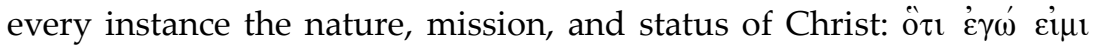

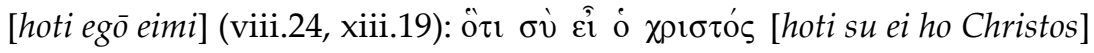

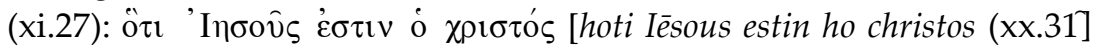

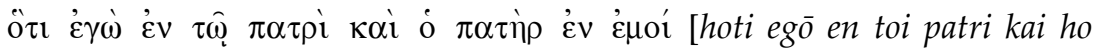

\footnotetext{
44 Tenney, "Topics from the Gospel of John. Part IV: The Growth of Belief," 344.
}

45 Howard, Christianity According to St. John, 158. 


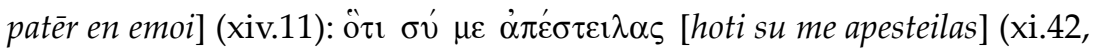

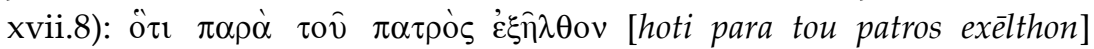

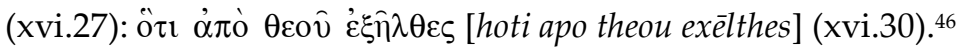

Thus Kysar summarizes the Johannine usage of $\pi \imath \sigma \tau \varepsilon v i \varepsilon v$ [pisteuein] as follows:

There are at least three different objects of faith for the Fourth Gospel. That is, what one is asked to believe or believe in varies.

1. Most often the point seems to be a personal allegiance to Jesus, a personal relationship with him....

2. Sometimes the object of the belief is not the person but the statements he or she makes. "Believe the words Jesus speaks" (see 2:22). This is not substantially different from the first object of faith, Jesus himself, except here faith is a credence in the statements of the revealer rather than faith in the person of the revealer. One implies the other....

3. A different thing is suggested, however, by the third object of faith. Sometimes it is faith in statements about Jesus. The reader is not asked to believe in the person of Jesus in the sense of a personal relationship of trust, nor asked to accept as true what Jesus says. The reader is, instead, called to believe that Jesus is the revealer, the Messiah, the Father's Son (e.g., 11:27). This use of the word "believe" has shifted the meaning of faith from a personal relationship to an intellectual acceptance. My faith is a faith in a creed, in this case, not in a person. ${ }^{47}$

From these citations it is quite clear that John has very definite conceptions of who Christ is. He is not an unimportant or nonexistent object of faith as the liberal theology suggests. Rather He is very God sent from God as the Messiah. From this discussion we conclude the following Johannine ideas about faith: Faith is not just a

\footnotetext{
46 Dodd, The Interpretation of the Fourth Gospel, 182-83.

47 Kysar, John: The Maverick Gospel, 93.
} 
correct theology, but it does include correct theology. Faith is the commitment of the total person to the person of Christ. In this faith commitment there is a knowledge by the believer that his object of faith is the living God who have been sent as the Messiah by God the Father. ${ }^{48}$

Having defined faith and showing the stress John places on it as opposed to reason, we are now ready to move to our next section of study regarding the structure of the book of John. Here we will be able to evaluate the Augustinian and the Tertullian views of evidences in regard to faith. This is so because of the great importance of the sign/miracles for the argument of the book of John. We will see if faith can ever be created by miracles (in contradiction to the Johannine theology of blindness and hatred regarding spiritual things of God). If we find that miracles cannot create faith, and man cannot produce it, we must find out how faith can ever come into existence at all under such hindrances.

\footnotetext{
48 Kysar writes, "The Gospel can use knowing as a synonym for believing, I think, because it uses the former work in something of its Hebraic sense. Even though the Gospel is written in Greek and its original readers understood Greek, it is likely that their backgrounds were, for the most part, Jewish. That led the Johannine Christians to think of knowledge in a Hebraic way. In the Hebrew Bible the word for 'knowing' had less of sense of cognitive or intellectual comprehension than did the comparable verb in the Greek language. Most often in the Hebrew Bible, knowing refers to a personal relationship. It is not detached apprehension of an object" (Kysar, John: The Maverick Gospel, 91).
} 


\section{The Significance of the Structure of John for the Faith-Reason Controversy}

While many pages could be written on the Johannine prologue, a foundational fact to be gleaned from analysis of it is that it impacts the meaning and message of the remainder of what follows it. ${ }^{49}$ The prologue serves as an introduction, a theological summary, and an interpretive guide for the rest of John's Gospel. Homer Kent writes,

In some respects this Prologue is the thesis and digest of the book. In it the author lays down his proposition that Christ, whom he calls the Word, is deity, was intimately involved at Creation, and has entered into human life so as to bring eternal life to as many as receive him. The rest of the Gospel is the unfolding and demonstration of this truth. ${ }^{50}$

Morris writes,

Morgan points out that we should not understand the term "Prologue" merely in the sense "Preface." "It is far more than a preface. In these eighteen verses we have an explanation of everything that follows from the nineteenth verse of chapter one, to the twentyninth verse of chapter twenty. All that follows is intended to prove the accuracy of the things declared in the first eighteen verses . . it is a summation; everything is found in those first eighteen verses." Similarly Godet sees it as "the summary of the testimonies which Jesus bore to Himself in the course of His ministry . . . it is at once the most normal and the richest expression of the consciousness which Jesus had of His own person" (I, p. 291). R. H. Lightfoot is emphatic: "These verses give the key to the understanding of this gospel, and make clear how the evangelist wishes his readers to approach his

49 See Herman Ridderbos, "The Structure and Scope of the Prologue to the Gospel of John," in Orton, ed., The Composition of John's Gospel, 41-62

50 Homer A. Kent Jr., The Light in the Darkness (Grand Rapids: Baker, 1974), 23. 
presentation of the Lord's work and Person." 51

It would be fair to call these eighteen verses the principium or presuppositions of John. Nowhere do we see a proof for God's existence. It is stated. Nowhere do we see proof of the Trinity, it is stated. Nowhere is there argument that the possibility of incarnation is logical or has actually truly occurred. It is stated to have happened. Nowhere is there dialectic over the nature of man. It is merely stated that man rejects God. It is presupposed that this incarnate God's purpose was to reveal the Father. If this analysis is correct, then again we see the Johannine stress on the priority of faith. He is saying in effect, that without this weltanschauung ("worldview") his book cannot be properly understood. Again we see the non-Johannine stance of Thomistic philosophy. Without the aid of revelation, the truths of God presented in his Gospel would be opaque. Georg Strecker explains,

Whoever sins has also fallen under the power of death $(8: 21,24) \ldots$ they do not understand; they reject the claim of the Revealer Jesus Christ, who wants to bring them into true freedom (8:31ff); they claim they are able to see and precisely for this reason they remain in the blindness of $\sin$ (9:41). Life in falsehood, sin, and subjection to death points to a situation that is objectively hopeless but of which the individual is not aware. This does not remove the responsibility of human beings for their own destiny but this makes clear that the problematic with which their situation is burdened transcends a purely intellectual understanding and concerns the reality of their existence. There is no escape hatch from one's being in this world of

51 Leon Morris, The Gospel According to John (rev. ed.; NICNT; Grand Rapids: Eerdmans, 1995), 63, n. 1. 
untruth; it is total. And this situation is all the more hopeless, since the worldly human being takes untruth for truth, darkness for light, and death for life (cf. 9:40-41).52

Thus the prologue is the code that unravels what is a mystery to man in darkness. Yet to look at the world from the perspective of John's prologue, one must already be a believer. Faith must precede reason.

At this point the reader may be saying that in spite of all the preceding points, this study has overlooked that Jesus did offer miracles and witnesses or "signs" to convince his audience, to compel them to faith. ${ }^{53}$ Further that the study has ignored a crucial term for the validity of human reason, namely, "to know." This, however, has not been an oversight, but rather a designed effort to show how misleading it is to understand the signs as instruments of faith, and avenues to knowledge of God. This will become most graphic as we study very briefly the growth of faith and unbelief in the argument of the book of John. If they are capable of producing faith, then our inspired author has written himself into a hopelessly inconsistent position.

As we begin our study of the growth of faith, it is again helpful to remember the structural device used by John in writing. Kent explains,

\footnotetext{
52 Georg Strecker, Theology of the New Testament (trans. M. Eugene Boring; Louisville: Westminster/John Knox Press, 2000), 489-90.

53 Cf. James M. Boice, Witness and Revelation in the Gospel of John (Grand Rapids: Zondervan, 1970), 88-113; Frank Thielman, Theology of the New Testament: A Canonical and Synthetic Approach (Grand Rapids: Zondervan, 2005), 162-70.
} 
John has arranged his Gospel around a selected group of signs performed by Jesus. He tells us this was his method (20:30-31). Included were eight miracles performed by Jesus (water to wine, nobleman's son, impotent man, feeding 5000, walking on water, man born blind, Lazarus, catch of fish), the resurrection of Christ, and perhaps the cleansing of the temple (2:18-23). By these signs our Lord demonstrated his authority and provided encouragement for men to trust him. ${ }^{54}$

J. H. Bernard comments on the purpose of the semei:a (sèmeia),

They were ... "signs" by which men might learn that He was the Christ ... and "believe on Him" ... The highest faith is that which can believe without a sign ... but signs have a useful function as bearing their witness to the glory of Jesus. This aspect of His signs is asserted by Jesus Himself (5:36). ${ }^{55}$

Our study will now be to determine whether the signs were successful to fulfill their purpose-faith in Jesus.

Our first occurrence of faith following a miracle is in 2:11 where his disciples believed after miracle number one was performed by Jesus. Is this initial faith of salvation? This would seem doubtful for they are already his disciples and have followed him since 1:37 where John the Baptist called Him the Lamb of God. The significance of this is that "to follow" is a synonym for "faith" in John. Lee explains,

The attitude of men towards Jesus is expressed in a variety of ways, although faith strictly has no synonym in the New Testament. Men's attitude towards the light is expressed by receiving . . (1.5), by

\footnotetext{
54 Kent, The Light in the Darkness, 22.

55 J. H. Bernard, A Critical and Exegetical Commentary on the Gospel according to St. John (ICC; New York: Charles Scribner's Sons, 1928), 1:81.
} 
coming ... or loving it $(3.20,21), \ldots$ We have also the expression, hearing his voice $(10: 4,5)$, coming unto him $(5: 40 ; 6.35,37,44,45,65)$, following him (8.12; 10.4, 5, 27; 21.19, 22), knowing him (10.14; 14.17; 17.3), seeing him (14.9), and, of course, pre-eminently, believing in him. ${ }^{56}$

Next we come to 2:23 (KJV), "Many believed in his name when they saw the miracles which he did." ${ }^{57}$ This our evidentialists might take as certain proof that miracles produce certain faith. Here we have the

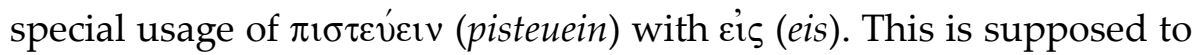
be a special usage by John to show genuine faith. Yet notice Jesus's response to them in 2:24. He did not entrust himself to them for $\mathrm{He}$ knew what was in man. Should He not have known that these people were believing in Him as a result of his miracles? Why did He not become intimate with them as they were believers? The answer is found in John 3 with Nicodemus. ${ }^{58}$ Jesus knew what was in "man" and now comes a "man" of the Pharisees. He too was a believer in Jesus because of the miracles (3:2). But was he saved? Clearly not, for Jesus told him he was in need of new birth by the Spirit. A closer look at 2:23 will show that ' $\pi\lrcorner \sigma \tau \varepsilon v \sigma \alpha \nu$ (episteusan, "believed") is an aorist indicative while $\theta \varepsilon \omega \rho o \tilde{v} \tau \varepsilon \varsigma$ (theōrountes, "seeing") is a present participle. This would seem to suggest that their faith was of little more duration than the time while they were actually seeing the

\footnotetext{
56 Lee, The Religious Thought of St. John, 230.

57 Cf. Nicolas Farelly, “John 2:23-25: What Kind of Faith Is This?" Presbyterian 30, no. 1 (Spring 2004): 37-45; Debbie Hunn, “The Believers Jesus Doubted: John 2:23-25," Trinity Journal 25, no. 1 NS (Spring 2004): 15-25.

58 Cf. L. John Topel, "A Note on the Methodology of Structural Analysis in Jn 2:23-3:21," Catholic Biblical Quarterly 33, no. 2 (April 1971): 211-20.
} 
miracles. It would be translated, "While they were seeing the miracles they believed."

Ladd gives us a good overview of several of the other sign/miracles,

After the healing of the sick man, many "followed" Jesus because of his signs (6:2). After the multiplication of the loaves, many confessed that he was the prophet who was to come into the world $(6: 14)$. However, while such a statement reflects a measure of faith, it is inadequate; for after Jesus explained that the reality behind the loaves pointed not to a victorious messianic King (6:15) but to a broken human body (6:51), "many of his disciples drew back and no longer went about with him" (6:66). The Gospel seems to indicate that a certain acceptance of signs is not a real belief. ${ }^{59}$

Another example of this same use of $\pi$ $\sigma \tau \varepsilon v i \varepsilon ı$ (pisteuein), the strong way of stating faith in John, is in 8:30-31a (ESV), "As he was saying these things, many believed in him. So Jesus was saying to those Jews who had believed in him. . .." Regarding this William Hendriksen writes,

Was this conviction genuine faith? Was it merely a mental persuasion or was it also wholehearted personal surrender? This question . . . becomes even more acute when it is borne in mind that the verses which follow show a swift change from belief to violent hostility. Not only does Jesus encounter verbal opposition (verse 33) but even verbal abuse (verse 48: "You are a Samaritan and have a demon"; cf. 52). At last there is even an attempt to stone him (verse 59). ${ }^{60}$

\footnotetext{
59 Ladd, A Theology of the New Testament, 311.

60 William Hendriksen, Exposition of the Gospel According to John (New Testament Commentary; Grand Rapids: Baker, 1954), 2:50.
} 
That this is the same group of people in both "belief" and "stoning" is seen for the following reasons: 1. $\pi \imath \sigma \tau \varepsilon v$ vıv (pisteuein) does not always indicate a change in heart so these may not be saved people (cf. 2:23), 2. There is nothing in the text to indicate that there is a break to switch to a new audience, 3 . The audience must be the same for verse 30 speaks of those believing in Him, and verse 31 says that Jesus spoke to those who had believed in Him. Those who had believed in Him were those just mentioned in the immediate context. The point of this illustration is to show that for John there are levels of faith. So to see an audience believing in Jesus after his miracles does not in itself prove that they are believers, that is in the true sense. Therefore, any claim that people can be converted through miracles or evidences or any other approach is nonsense. John gives absolutely no ground for evidentialists to Thomistic apologists.

What then is the role of signs in John? It would be simply to confirm the faith of those who have it, and show how wicked the unbeliever really is for he refuses to come to true faith to the light from his darkness of sinful rebellion. Ladd comments,

The question of the relationship of the signs to faith is not easy... The answer must be found in a sort of tension between signs and faith. It requires faith to recognize the true meaning of the signs and their witness to Jesus; to those who had no faith, the signs are merely meaningless prodigies. To those who are responsive, the signs are the means of confirming and deepening faith. It is clear that Jesus' signs were not designed to compel faith. On the other hand, the works of Jesus are sufficient testimony to those able to see what is happening in his mission. Jesus' works will serve as a means of condemnation and 
confirming blind men in their sinfulness.... (15:24). ${ }^{61}$

The most outstanding blow to Thomistic apologetics which seeks to convince men through reasoning is found in John 12:37-40 (KJV, emphasis added):

But though he had done so many miracles before them, yet they believed not on him; That the saying of Esaias the prophet might be fulfilled, which he spake, Lord, who hath believed our report? and to whom hath the arm of the Lord been revealed? Therefore, they could not believe, because Esaias said again, He hath blinded their eyes, and hardened their heart; that they should not see with their eyes, nor understand with their heart, and be converted, and I should heal them.

Why was it that men could not believe the signs which should have been so convincing? It was because God had decreed it such by the inspired writer Isaiah (John 12:39). B. F. Westcott explains,

The fact which has already been noted... is now traced back to its ultimate origin which lay in the divine action. They did not believe and they could not believe.... The want of belief was involved in the necessary truth of the prophetic word. ${ }^{62}$

If John is consistent, and he has been so far, his concept of knowledge should be an outgrowth of faith, and faith should be a result of the work of God in the heart of a dead sinner. Let us discuss these thoughts along with other pertinent matters in our final section of this study.

61 Ladd, A Theology of the New Testament, 310.

62 B. F. Westcott, The Gospel According to St. John (Grand Rapids: Eerdmans, 1973), 185. 


\section{The Johannine Emphasis on the Divine Initiative in Salvation Joined with the Doctrine of Human Inability to Believe and the Significance of These Doctrines for the Faith-Reason Controversy}

The first matter we must discuss is John's view of the origin of faith and his view of knowledge. Howard's remarks are helpful,

What then is the place of Knowledge in the Christian experience, and how does it stand related to Faith?... In the New Testament generally, as also in St. John, faith and sight are certainly opposed to one another. But faith and knowledge are far more closely related. Thus Peter's confession says, "We have believed and know that thou art the Holy One of God" [John vi.9], whereas we read in the First Epistle, "We know and have believed the love which God has in us" [1 John iv.16]. Commenting on the former, Bernard says: "While John does not lay down formulae as the relative precedence of faith and knowledge in regard to the things of the spirit, his teaching is nearer the credo ut intelligam of the saints than the intelligo ut credam of the philosophers..." 63

The high view of knowledge in relationship to faith is seen in that Jesus defines eternal life itself as knowing God. John 17:3 (KJV), “And

63 Howard, Christianity According to St. John, 164. The contrast between those two approaches was already formulated by Augustine (see below) and taken up again by Anselm (1033-1109); Anselm stated, "For I do not seek to understand that I may believe, but I believe in order to understand. For this also I believe, - that unless I believed, I should not understand" (Proslogium 1; St. Anselm, Proslogium; Monologium; An Appendix in Behalf of the Fool by Gaunilon; and Cur Deus Homo [trans. Sidney Norton Deane; La Salle, Ill.: Open Court, 1948], 7). The Latin text reads, "Neque enim quæro intelligere ut credam, sed credo ut intelligam. Nam et hoc credo: quia ^nisi credidero, non intelligam «." St. Anselm, Opera Omnia (Edinburgh: Thomas Nelson, 1946), 1:100. The notes of this edition indicate several passages where this phrase occurs in Augustine and indicates the similarity between the end of the quote to Isaiah 7:9 in the Vulgate. For more on Anselm's approach, see Edgar and Oliphint, eds., Christian Apologetics Past and Present, 1:365-94, and Bush, Classical Readings in Christian Apologetics, 237-54. 
this is life eternal, that they might know thee, the only true God, and Jesus Christ, whom thou has sent." Eternal life was to be gained only by faith as we are told in John 3:16. ${ }^{64}$ If knowledge is eternal life, and faith is the only basis for eternal life then faith and knowledge must intimately be united. This also shows why John gives no stress to arguments. Faith must precede all knowledge in the spiritual realm. Michel writes,

Faith and knowledge (Jn. 6:69), knowledge and faith (Jn. 17:8; 1 Jn. 4:6), are not two processes distinct from each other, but instructive coordinates which speak of the reception of the testimony from different standpoints. Faith alone which receives the testimony possesses knowledge; he who knows the truth is pointed to faith. The coordination of knowledge and faith is anti-gnostic and anti-speculative. The hearer should understand that both are involved in salvation: acceptance of the testimony as well as personal response and reformation that conforms to the testimony. ${ }^{65}$

From all this, it is seen that reason can neither precede faith, nor, can faith ever be severed from reason. With these two prongs of Thomistic apologetics excised, it is utterly destroyed as a Biblical method. Augustine's famous dictum "I believe in order to understand" is vindicated. ${ }^{66}$ The great stress on signs and evidences

64 Cf. William R. Domeris, “The Confession of Peter According to John 6:69," Tyndale Bulletin 44, no. 1 (1993): 155-67.

65 O. Michel, “Faith,” NIDNTT 1:603.

66 It is noteworthy that Augustine's saying appears in his commentary on John 7:16-17 where he also quotes Isaiah 7:9 and John 6:29; thus, his reflection on the relation to faith and knowledge stems from his analysis of John's theology. Augustine argues, "Therefore do not seek to understand in order to believe, but believe that thou mayest understand; since, 'except ye believe, ye shall not understand' [Isa. 7:9]"; Augustine, Tractates on the Gospel of John 29:6 (NPNF1 7:184); in the Latin original the text reads, "Ergo noli quærere intelligere ut credas, sed crede ut 
as confirmatory to the God imparted faith, destroys any mysticism that would do away with reason altogether as in the more extreme thought of Tertullian or the mystic St. Bernard of Clairvaux. ${ }^{67}$

Obviously John must hold to faith as a gift from God. He has stripped the natural man of every possibility of knowing God. Although this seems terribly harsh, Augustine has also affirmed this against Pelagianism in his famous cry to God, "Give what Thou Commandest, and command what Thou willest." 68 In the context of Augustine's writing here, we gather that what "God primarily and chiefly command" is "that we believe on Him." This is rooted in the system of John where man can never know God. God must make himself known to man. This He does through his electing work, his revelation and accomplished redemption in his Son, and in the

intelligas; quoniam nisi credideritis, non intelligetis [Isa. 7:9]." (PL 35.1630). The Vulgate of Isaiah 7:9 reads, "si non credideritis non permanebitis"; while the Septuagint is even closer to

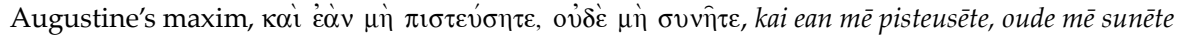
["and if you do not believe, neither will you understand"].

67 For more on Bernard of Clairvaux and his view of faith, see G. R. Evans, Bernard of Clairvaux (Great Medieval Thinkers; New York: Oxford University Press, 2000), esp. 44-48. For a selection of key texts by Bernard of Clairvaux, see Dennis E. Tamburello, ed., Bernard of Clairvaux: Essential Writings (New York: Crossroad, 2000).

68 Augustine, The Gift of Perseverance 53 (NPNF1 5:547). In Latin, "Da quod jubes, et jube quod vis" (PL 45.1026). In his work on perseverance directed against the Pelagians, Augustine indicates that he had used this phrase in his Confessions before the controversy and that Pelagius at Rome was irritated by the saying and its possible abuses. The saying is a recurring refrain in Augustine's classic, his Confessions; see Augustine, Confessions 10.29.40, 10.31.45, and 10.37.60 (NPNF 1:153, 155, 159; PL 32.796, 798, 804). On the debate between Augustine and Pelagius, see Robert F. Evans, Pelagius: Inquiries and Reappraisals (New York: Seabury, 1968), esp. 71, and Henry Chadwick, The Early Church: The Story of the Emergent Christianity from the Apostolic Age to the Foundation of the Church of Rome (New York: Penguin, 1967), 225-35. Augustine's famous phrase shows similarities with New Testament passages such as Mark 6:22 describing Herod's deviant kingly power, and especially with the Johannine text John 11:22 describing Martha's faith in God's power through the intercession of Christ. 
efficacious drawing of the Holy Spirit. In closing this study, allow me to document each of these above statements from John's own thought.

Faith is seen to be a gift of God in John 6:27-44. Jesus tells his audience to labor for food that perishes not which He will give to them, which is eternal life. This laboring is believing. Next in verse 37 we are told also that those who come to Christ to gain this bread are all given to Christ by the Father. Then finally in verse 44 Jesus says that no man can come to Him unless the Father draws him. This clearly teaches that faith is a gift of God since "coming" is the same as "believing." That these two words have the same meaning can be seen by referring Lee's earlier quotation (cf. above) regarding the synonyms for faith. Schneider also agrees,

For the coming of men to Christ, however, the final authority is not the will of man but God. According to John, the answer to the question who come to Jesus is those who are taught by God (6:45). If we then ask how they come, the answer is that none can come unless the Father draw him. Coming to Jesus is a coming effected by God. The apparently free decision of man is a decision ordained by God. Behind the Johannine statements stands the thought of divine election (cf. 6:65). Those who thus come to Jesus believe in Him. ${ }^{69}$

Here we see, then, that man comes to God because God gives him the faith. We also see the electing work of God.

That Jesus is the revelation of the Father and the accomplisher of redemption is extremely clear in John 1:18 (where the Son declares the Father), and John 1:29 ("Behold, the Lamb of God, who takes

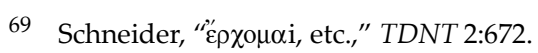


away the sins of the world! [ESV]).

That the Spirit is the effecting agent in time of the act of regeneration is seen clearly in John 3:5. A birth is not something brought about by the child who is born. The child is passive. So also the Holy Spirit brings about salvation to the elect by giving them life.

John's doctrine of God's initiative in human salvation is reinforced by the Johannine insistence upon human inability in the spiritual realm. Thus we find the unregenerate man cannot see (ov

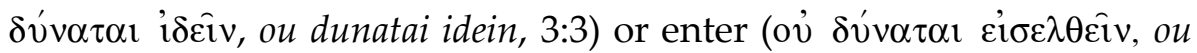
dunatai eiselthein, 3:5) the kingdom of God. The unbeliever on his own

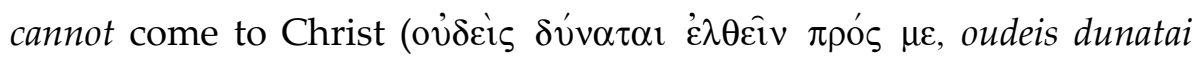
elthein pros me, 6:44). ${ }^{70}$ Why do unbelievers not know or understand ( $\gamma \mathrm{\iota} \omega \dot{\sigma} \sigma \varepsilon \tau \varepsilon$, ginōskete) Christ's teaching? It is because they cannot hear

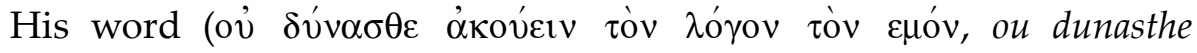

70 The exegetical case for this is well made by D. A. Carson, The Gospel According to John (Grand Rapids, Mich.: Eerdmans, 1991), 292-93. There he writes, “The grumbling was not only insulting, but dangerous: it presupposed that divine revelation could be sorted out by talking the matter over, and thus diverted attention from the grace of God. 'So long as a man remains, and is content to remain, confident of his own ability, without divine help, to assess experience and the meaning of experience, he cannot 'come to' the Lord, he cannot 'believe'; only the Father can move him to this step, with its incalculable and final results' (Lightfoot, pp. 160-161). "The thought of v. 44 is the negative counterpart to v. 37a. The latter tells us that all whom the Father gives to the Son will come to him; here we are told that no-one can come to him unless the Father draws him ( $c f$. Mk. 10:23ff.). And again, it will be Jesus himself who raises such a person up at the last day. The combination of v. 37a and v. 44 prove that this 'drawing' activity of the Father cannot be reduced to what theologians sometimes call 'prevenient grace' dispensed to every individual, for this 'drawing' is selective, or else the negative note in v. 44 is meaningless. Many attempt to dilute the force of the claim by referring to 12:32, where the same verb for 'to draw' (helkyō) occurs: Jesus there claims he will draw 'all men' to himself. The context shows rather clearly, however, that 12:32 refers to 'all men without distinction' (i.e. not just Jews) rather than to 'all men without exception'. Yet despite the strong predestinarian strain, it must be insisted with no less vigour that John emphasizes the responsibility of people to come to Jesus, and can excoriate them for refusing to do so (e.g. 5:40)." 
akouein ton logon ton emon, 8:43). The hopeless estate of the world on its own is underscored by the fact that the Helper ( $\pi \alpha \rho \alpha \kappa \lambda \eta \tau \sigma \varsigma$, parakletos, 14:16), the Spirit of Truth ( pneuma tēs aletheias, 14:17) is the very one the world cannot receive or

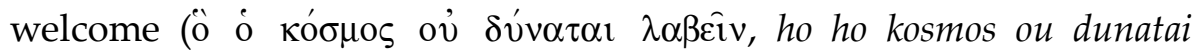
labein, 14:17). ${ }^{71}$ The emphatic summary of human spiritual inability is found in John's account of Jesus as the True Vine and his followers as branches that abide or remain connected to the life-giving Vine. In 15:4-5 (ESV) Jesus teaches,

Abide in me, and I in you. As the branch cannot bear fruit by itself, unless it abides in the vine, neither can you, unless you abide in me. I am the vine; you are the branches. Whoever abides in me and I in him, he it is that bears much fruit, for apart from me you can do nothing.

Thus just as a branch cannot bear fruit without the vine ( $\tau$ ò $\kappa \lambda \hat{\eta} \mu \alpha$ ov

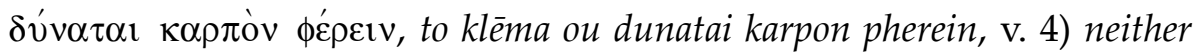

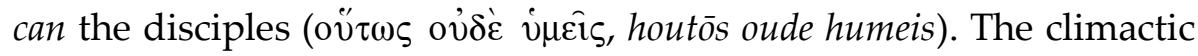
statement is decisive and comprehensive: "for apart from me you can

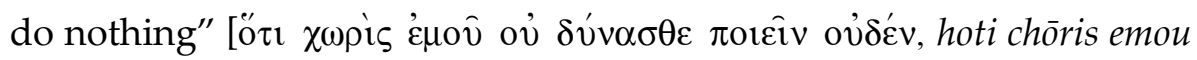
ou dunasthe poiein ouden, v. 5). The unbeliever exists in a state of utter spiritual helplessness when left to himself. In terms of apologetic arguments in and of themselves, then, what can they possibly accomplish?

This understanding of man's inability in the spiritual realm as

\footnotetext{
71 Other relevant examples of human inability expressed by John with ov $\delta v i v \alpha \tau \alpha \mathrm{l}$ (ou dunatai) are found in $7: 34 ; 8: 21 ; 13: 33$.
} 
reflected by the Fourth Gospel was the understanding of the theology of the early reformers including Luther, Zwingli, and Calvin. One of the prerequisites for the Reformation to occur, was a break with the Thomistic insistence upon the sufficiency of human reason to know spiritual truth. Thus, the pre-Reformation Luther's comments on Romans 3:11 are quite significant. The text reads (KJV), "There is none that understandeth, there is none that seeketh after God." Luther writes,

No one understands, because the wisdom of God is hidden, unknown to the world. For "The Word became flesh" (John 1:14), and Wisdom was made incarnate and is thus hidden and unapproachable except by understanding, just as Christ cannot be known except by revelation. Therefore those who are wise only in regard to visible things and in the realm of visible things (such as all men are outside of faith who do not know God and the life to come), do not understand, are not wise, that is, they are not intelligent or truly wise but stupid and blind; and although they may seem to be wise in their own eyes, yet they have become fools. For they are wise only with a wisdom which can be found by human means but not in hidden things. ${ }^{72}$

The spiritual inability of the unbeliever has been a hallmark of Reformed theology since its earliest days. Zwingli's sentiments, for example are remarkable when one remembers that his education had been in the humanism of the late renaissance as exemplified by Erasmus. Yet in spite of humanism, Zwingli emphasized man's inability and the necessity of divine enablement drawing upon John's

72 Martin Luther, Lectures on Romans: Glosses and Scholia (trans. Jacob A. O. Preus; ed. Hilton C. Oswald; Luther's Works 25; Saint Louis: Concordia, 1972), 223. 
teachings in his sermon, "Of the Clarity and Certainty or Power of the Word of God,"

None can come to the Lord Jesus Christ except he has learned to know him of the Father. And note who the teacher is: not doctores, not patres, not pope, not cathedra, nor concilia, but the Father of Jesus Christ. And you cannot say, we are taught of men as well. No, for just before he says: "No man can come to me, except my heavenly Father draw him" [John 14:6]. Even if you hear the gospel of Jesus Christ from an apostle, you cannot act upon it unless the heavenly Father teach and draw you by the Spirit. The words are clear; enlightenment, instruction and assurance are by divine teaching without any intervention on the part of that which is human. And if they are taught of God, they are well taught, with clarity and conviction: if they had first to be taught and assured by men, we should have to describe them as taught of men rather than God.73

Calvin, above all of the Reformers, insisted that the Word of God was undemonstrable to fallen human reason, and that it was a product of only the work of the Spirit of God as He witnessed to the heart of the believer. Note here first, that Calvin joins the authority of Scripture with the internal witness of the Spirit or the self-authentication of Scripture and contrasts this with subjecting it to proof and reasoning. He writes,

Let this point therefore stand: that those whom the Holy Spirit has inwardly taught truly rest upon Scripture, and that Scripture indeed is self-authenticated; hence, it is not right to subject it to proof and reasoning. And the certainty it deserves with us, it attains by the testimony of the Spirit. For even if it wins reverence for itself by its

73 Ulrich Zwingli, "Of the Clarity and Certainty or Power of the Word of God," in Zwingli and Bullinger (ed. and trans. G. W. Bromiley; The Library of Christian Classics 24; ed. John T. McNeill; Philadelphia: Westminster Press, 1953), 79-80. 
own majesty, it seriously affects us only when it is sealed upon our hearts through the Spirit. Therefore, illumined by his power, we believe neither by our own nor by anyone else's judgment that Scripture is from God... (Calvin, Institutes 1.8.5) ${ }^{74}$

Note especially the sentence, "It is not right to subject it to proof and reasoning." Accordingly, Calvin insists that the role of evidences is as a secondary aid to human feebleness, that is, for confirmation. He writes,

Therefore, Scripture will ultimately suffice for a saving knowledge of God only when its certainty is founded upon the inward persuasion of the Holy Spirit. Indeed, these human testimonies which exist to confirm it will not be vain if, as secondary aids to our feebleness, they follow that chief and highest testimony. But those who wish to prove to unbelievers that Scripture is the Word of God are acting foolishly, for only by faith can this be known. (Calvin, Institutes 1.8.13; Battles 1:92)

Calvin emphatically rejects the use of evidences as proofs to unbelievers. He says, "But those who wish to prove to unbelievers that Scripture is the Word of God are acting foolishly, for only by faith can this be known." In other words, the traditional approach to apologetics as we designate it today, for Calvin is "foolishness." 75

\footnotetext{
74 John Calvin, Institutes of the Christian Religion (trans. Ford Lewis Battles; 2 vols.; 1960; reprint, Philadelphia: Westminster/John Knox Press, 2006), 1:80.

75 Cf. here, The Westminster Confession of Faith 10.1, "Of Effectual Calling": "All those whom God hath predestinated unto life, and those only, He is pleased , in his appointed and accepted time, effectually to call, by his Word and Spirit, out of that state of sin and death, in which they are by nature, to grace and salvation by Jesus Christ; enlightening their minds, spiritually and savingly, to understand the things of God: taking away their heart of stone, and giving unto them an heart of flesh; renewing their wills, and by his almighty power determining them to that which is good, and effectually drawing them to Jesus Christ; yet so as they come most freely, being made willing by his grace."
} 


\section{John's Conception of Truth and the Internal Witness of the} Holy Spirit

At the core of all Christian apologetic methods are attempts at establishing and defending the truth of the Christian faith. Accordingly John portrays Pilate as he judges Christ as pondering the problem of truth. "What is truth?" Pilate asks in 18:38. His question arose in response to Jesus's declaration that His ministry was to witness to the truth: "For this purpose I was born and for this purpose I have come into the world-to bear witness to the truth. Everyone who is of the truth listens to my voice" (18:37 ESV). Indeed, Jesus' self-identification was with truth, "I am the way, and the truth, and the life. No one comes to the Father except through me" (14:6 ESV). Roger Nicole argues that truth is inseparably connected with God and his revelatory Word that points us to the truth of Christ. ${ }^{76}$

Christian apologetics believes that truth is inescapable. Vern Poythress demonstrates that one engages the question of truth, and of God himself, even in what seems to be the chance event of flipping a coin.

76 Roger Nicole writes, "Truth, in the biblical sense, is ultimately associated with the triune God Himself as a perfection of His being. By His singular mercy truth is communicated in a finite though adequate measure to rational creatures, angelic and human, so they can distinguish between truth and error, veracity and mendacity, straightforwardness and deceptiveness. God is always on the side of what is true and right. Specifically He is always true to His word, so that faithfulness appears as a wondrous feature of His being, grounding full confidence on the part of believers. In His faithfulness God will not stop with prefigurements and foreshadowings, but will provide to those who worship Him, true light, true bread, true life in Jesus Christ, the Savior full of grace and truth, who brought life and immortality to light through the Gospel (John 1:14; 2 Tim. 2:10)" (Roger Nicole, "The Biblical Concept of Truth," in D. A. Carson and John D. Woodbridge, eds., Scripture and Truth [Grand Rapids: Baker, 1992], 296). 
We can arrive at the same conclusion by considering the issue of truth. It is true that when I flipped the coin, the result was tails. The truth about the result, and the truths about the processes leading to the result, show divine attributes. Truth is immutable, invisible, immaterial, everywhere present. It is also rational and language-like. All these are attributes of God. Why? Because truth belongs first to God's mind. Truth is what God knows. God's mind is divine, and all his attributes are expressed in everything he thinks, everything he plans, and everything he says. We see the imprint or reflection of God and his attributes when we deal even with one truth, namely, the truth that the coin came up tails. We know God and his attributes, because they are "plain" in the things that he has made. But we will not acknowledge God. We do not give him thanks. We rebel. Rebellion against God is deep within us. It is so deep that it covers its tracks. We do not realize the depth of our rebellion because we make excuses. And we make substitutes, like Chance as a substitute, or fortunetellers as a substitute source for security, without even realizing that we are betraying God in the process. Romans 1:21 has said it: "their foolish hearts were darkened."77

This foundational concern for truth is inherent in Johannine theology as truth is manifestly a vital concern of John's Gospel. ${ }^{78}$ Andrew T. Lincoln argues that the Fourth Gospel develops a conscious and extensive use of the image of a lawsuit, with truth itself on trial. ${ }^{79}$ Moreover, God's truth can either be sovereignly revealed or

\footnotetext{
77 Vern Poythress, Chance and the Sovereignty of God: A God-Centered Approach to Probability and Random Events (Wheaton: Crossway, 2014), 120.

78 See Marshall, New Testament Theology, 537-38; Ignace de la Potterie, "The Truth in Saint John (1963)," in John Ashton, ed. The Interpretation of John (2nd ed.; Edinburgh: T\&T Clark, 1997), 6782; Strecker Theology of the New Testament, 429-31; Geerhardus Vos, "'True' and 'Truth' in the Johannine Writings," in Redemptive History and Biblical Interpretation: The Shorter Writings of Geerhardus Vos, ed. Richard B. Gaffin Jr. (Philipsburg: P \& R, 1908), 343-51; repr. from The Biblical Review 12 (1927): 507-20.

79 Andrew T. Lincoln, Truth on Trial: The Lawsuit Motif in the Fourth Gospel (Peabody: Hendrickson, 2000).
} 
concealed. ${ }^{80}$ This reality, evident in the Fourth Gospel in passages such as 1:11-13; 10:14-16, 25-31; 12:37-50; 17:1-3, 6, 9, 22-24, may reflect the Qumran community and teachings in the Dead Sea Scrolls. ${ }^{81}$ Whether such is the case, it is evident that John recognized that the truths brought by Jesus would not be understood as truth apart from divine sovereign intervention in the hearts of sinners blinded by the darkness of sin according to God's own purpose. ${ }^{82}$

80 Cf. Todd A. Scacewater, “The Predictive Nature of Typology in John 12:37-43," Westminster Theological Journal 75 (2013): 129-43.

81 Ashton writes, “'At Qumran', concludes de la Potterie, '[the term "truth"] comes to denote the ensemble of the religious ideas of the sons of the Covenant.' The covenanters saw this truth as a privileged possession bestowed on them by God (1QM13:12), something not lightly to be divulged to others, recommending instead 'faithful concealment of the mysteries of truth' (1QS4:6), a well-known passage that pits the spirit of light against the spirit of darkness and falsehood and claims for the community the title of 'sons of truth in this world' (cf. 1QS2:24, 'the community of truth').

"The truth of the Gospel may appear less exclusive than the jealously guarded secrets of the Qumran community. Jesus, after all, is 'the light of the world' and his message is available to all prepared to listen. But the esoteric side of Johannine Christianity should not be lost sight of either. 'Truth' is such a generous, open-sounding word that all commentators without exception have failed to recognize that like the alternative terms for revelation 'living water' and 'bread of life' it too belongs to what Herbert Leroy calls John's Sondersprache-his private language. 'He who is of the truth hears my voice' (18:37). But what of those who are not of the truth, such as Pilate, to whom these words are spoken, and 'the Jews', who react with angry incomprehension when told that the truth will set them free (8:32)? The only question in the Gospel that actually takes the form of a riddle is Pilates's 'What is truth?' And, as we know, he would not stay for answer" (Ashton, Understanding the Fourth Gospel, 506-7). Cf. J. Gerald Janzen, "II Am the Light of the World' (John 8:12): Connotation and Context," Encounter 67, no. 2 (2006): 115-35.

82 Carson writes, "Some explanation must be given for such large-scale, catastrophic unbelief. There is ample evidence that the substantial unbelief of the Jewish people before the resurrection was a major hindrance to the conversion of Jews after the resurrection. Surely (it was argued) we may call into question the messianic claims of one so thoroughly rejected by the Jewish people by whom and for whom the prophetic Scriptures were written! The Christian answer, as clearly articulated in Paul (esp. Rom. 9-11) as here, is that this unbelief was not only foreseen by Scripture but on that very account necessitated by Scripture. Although the Greek conjunction hina sometimes has resultative force (the meaning here would then be that the unbelief of the people resulted in the fulfillment of Old Testament prophecy, not that it occurred in order that Old Testament prophecy might by fulfilled), no such weakening can be legitimate 
Thus for John, truth is not just important, the knowledge of spiritual truth is intimately connected with the person and work of the Holy Spirit. ${ }^{83}$

Various approaches toward an articulation of Johannine pneumatology have been developed. ${ }^{84}$ This is due in part to John's distinctive presentation of the Holy Spirit's person and work in comparison with the Synoptic Gospels. ${ }^{85}$ Two examples of John's unique emphases are a pre-Pentecostal giving of the Spirit (20:22-

here: v. 39 insists that it was for this reason that the people could not believe. On the other hand, such unambiguous predestinarianism is never set over against human responsibility: v. 37 presumes there is human culpability, and v. 43 articulates an utterly reprehensible human motive for the unbelief. Meanwhile, v. 32 draws attention to those Jews who do believe. Philosophically, like every major author in the canon, John is a compatibilist (cf. Carson). Theologically, John is summarizing a truth presented throughout the Fourth Gospel: by and large the nation of Israel refused the regeneration through the Spirit that lay at the core of the promised new covenant ( $c f .3: 3-5)$. Israel's leaders thought they could see when they were blind (9:39-41). This emphasis was already set out in the Prologue (1:10, 11)" (Carson, The Gospel According to John, 447-48). Cf. Donald E. Hartley, "Destined to Disobey? Isaiah 6:10 in John 12:37-41," Calvin Theological Journal (2009): 265-87.

83 It is instructive to note that B. B. Warfield while deeply Reformed in theology did not favor the implications of the internal witness of the Holy Spirit as developed by presuppositional apologetics as represented in his day by Abraham Kuyper. Benjamin B. Warfield writes, "... the mystical tendency is showing itself in our day most markedly in a widespread inclination to decline Apologetics in favor of the so-called testimonium Spiritus Sancti. The convictions of the Christian man, we are told, are not the product of reasons addressed to his intellect, but are the immediate creation of the Holy Spirit in his heart. ... It is easy, of course, to say that a Christian man must take up his standpoint not above the Scriptures, but in the Scriptures. He very certainly must. But surely he must first have Scriptures, authenticated to him as such, before he can take his standpoint in them. It is equally easy to say that Christianity is attained, not by demonstration, but by a new birth. Nothing could be more true. But neither could anything be more unjustified than the inferences that are drawn from this truth for the discrediting of Apologetics" (Benjamin B. Warfield, introductory note to Apologetics, by Francis R. Beattie [Richmond: The Presbyterian Committee of Publication, 1903], 20, 24).

84 Tricia Gates Brown, Spirit in the Writings of John: Johannine Pneumatology in Social-scientific Perspective (JSNTSup 253; New York: T\&T Clark, 2003), 62-74.

85 Cf. Ladd, A Theology of the New Testament, 324-28. 
$23)^{86}$ and his presentation of the upper room discourse that preserves Jesus's teachings concerning the Spirit's role as Paraclete. ${ }^{87}$

An obvious connection of truth and the Spirit in the theology of John is seen in Jesus's well known teaching concerning true worship. ${ }^{88}$ Jesus declares to the Samaritan woman: "But the hour is coming, and is now here, when the true worshipers will worship the Father in spirit and truth, for the Father is seeking such people to worship him. God is spirit, and those who worship him must worship in spirit and truth" (4:23-24 ESV). The Father's search for those who worship Him in Spirit and truth is realized only as worship and honor flow to God and His Son from a Christ-centered life that is not possible without God's granting of spiritual resurrection in Christ (see 5:19-29). Spiritual renewal through the Holy Spirit is necessary due to the inescapable and incapacitating impact of sin on believer and unbeliever alike (John 1:29; 3:36; 8:7, 34; 1 John 1:7-10). ${ }^{89}$

All of this establishes why the regenerating work of the Holy Spirit is a prerequisite in the defense of the faith. For the unbeliever to move from unbelief to saving faith, there must be more than

86 See Gary M. Burge, The Anointed Community: The Holy Spirit in the Johannine Tradition (Grand Rapids: Eerdmans, 1987), 198-221.

87 Ladd, A Theology of the New Testament, 325, 329-32.

88 Rudolf Schnackenburg, "Worship in Spirit and Truth," in Christian Existence in the New Testament (trans. Joseph Blenkinsopp; vol. 2; Notre Dame: University of Notre Dame Press, 1969), 85-114.

89 Schnackenburg, "Christ and Sin According to John," in Christian Existence in the New Testament, $115-50$. 
arguments and evidence to overcome such fatal incapacity. ${ }^{90}$ In John's theology, this is provided by the divine gift of the Holy Spirit. Herman N. Ridderbos argues that John himself was dependent upon the witness of the Spirit as he composed his Gospel. ${ }^{91}$ This aspect of the Spirit's ministry has been termed the internal witness of the Holy Spirit. James M. Boice writes,

Ever since the publication of Luther's Small Catechism in 1529, the publication of the expanded Institutes of the Christian Religion thirty years later, and the appearance in those years of several other less influential Reformation volumes, the idea of the witness of the Spirit in the Fourth Gospel has been central to that doctrine which reformed theologians have called the internal witness of the Holy Spirit (testimonium Spiritus Sancti internum). By this phrase is meant the supernatural and saving activity of the Holy Spirit on behalf of the one who hears the Gospel so that the reality of what is taught is conveyed to the mind, producing the conviction that this is truth and leading the soul to receive it to its consequent salvation. Luther taught that the Holy Spirit "calls, gathers, enlightens, and sanctifies the whole Christian Church on earth." And Calvin added that the "the Word will not find acceptance in men's hearts before it is sealed by the inward testimony of the Spirit. . . . Without the illumination of the Holy Spirit, the Word can do nothing" [Luther, Small Catechism, article

90 Calvin writes, "There are other reasons, neither few nor weak, for which the dignity and majesty of Scripture are not only affirmed in godly hearts, but brilliantly vindicated against the wiles of its disparagers; yet of themselves these are not strong enough to provide a firm faith, until our Heavenly Father, revealing his majesty there, lifts reverence for Scripture beyond the realm of controversy. Therefore Scripture will ultimately suffice for a saving knowledge of God only when its certainty is founded upon the inward persuasion of the Holy Spirit. Indeed, these human testimonies which exist to confirm it will not be in vain if, as secondary aids to our feebleness, they follow that chief and highest testimony. But those who wish to prove to unbelievers that Scripture is the Word of God are acting foolishly, for only by faith can this be known. Augustine therefore justly warns that godliness and peace of mind ought to come first if a man is to understand anything of such great matter" (Calvin, Institutes 1.8.13; Battles, 1:92; Italics mine).

91 Herman N. Ridderbos, The Gospel According to John: A Theological Commentary (trans. John Vriend; Grand Rapids: Eerdmans, 1997), 14-16. 
3; Calvin, Institutes $1.7 .4 ; 3.2 .33]$. Because the reformed doctrine of the Holy Spirit has always been based in a large measure upon the teachings of the Fourth Gospel, it is in reference to this doctrine that John's use of the words "witness" and "testimony" has always been most clearly referred to revelation. ${ }^{92}$

To underscore the reality of the Spirit's inner witness, there is also John's unique declaration in 16:8-11 of the elenctic work of the Holy Spirit in his mission to the world. "If the primary function of the Spirit to believers is that of teacher and interpreter, he is to the world an accuser." 93 This reality has been recognized to have significant relevance for the work of missiology. Thus J. H. Bavinck declares,

When we speak of elenctics we do well to understand it in the sense that it has in John 16:8. The Holy Spirit will convince the world of sin. The Holy Spirit is actually the only conceivable subject of this verb, for the conviction of sin exceeds all human ability. Only the Holy Spirit can do this, even though he can and will use us as instruments in his hand. Taken in this sense, elenctics is the science which is concerned with the conviction of $\sin$. In a special sense then it is the science which unmasks to heathendom all false religions as sin against God, and it calls heathendom to a knowledge of the only true God. To be able to do this well and truthfully it is necessary to have a responsible knowledge of false religions, but one must also be able to lay bare the deepest motifs which are therein expressed. This can actually occur only if one recognizes and unmasks these same undercurrents within himself. Elenctics is possible only on the basis of a veritable selfknowledge, which is kindled in our hearts by the Holy Spirit. ${ }^{44}$

\footnotetext{
92 Boice, Witness and Revelation, 143.

93 Ladd, A Theology of the New Testament, 333.

94 J. H. Bavinck, An Introduction to the Science of Missions (trans. David Hugh Freeman; Philadelphia: P \& R, 1960), 222.
} 
Thus in Johannine thought, the ministry of the Holy Spirit is normative for the believer, not just a prerequisite for saving faith for the unbeliever. ${ }^{95}$

In Johannine theology, the Holy Spirit is the Spirit of Truth $(14: 17 ; 16: 13)$. The Spirit is the one who reveals God as He is "sent by the Father" in Christ's "name" (14:26). Thus the Spirit, the "Helper" ( $\pi \alpha \rho \alpha ́ \kappa \lambda \eta \tau o \varsigma$, paraklētos, 14:16, 26) witnesses to Christ (15:26) and reminds the Church of Christ's teaching (14:26), guiding the Church into truth (16:13-14). In fact, "the Spirit of Truth" is the one "whom the world cannot receive, because it neither sees him nor knows him" (14:17 ESV). But in contrast with the world, Jesus declares to his disciples that they "know him, for he dwells with you and will be in you" (14:17).

All of this underscores that Johannine theology asserts the radical inability of the unbeliever to know God. The world is not morally unfettered and intellectually neutral about spiritual realities. Instead, the world hates the message of the Son of God:

\footnotetext{
95 Marshall writes, "First John does not mention the resurrection of Jesus, although it assumes that he is in heaven and has access to the Father (1 Jn 2:1) and that believers can have a spiritual relationship with him. Statements about anointing with the Spirit express the Gospel teaching about the Spirit being given to believers (Jn 7:39; 20:22) using a new metaphor (1 Jn. 2:20, 27)" (Marshall, New Testament Theology, 569). Stephen S. Smalley writes, "There are thus good grounds for understanding $\chi \rho \hat{\rho} \sigma \mu \alpha[$ [chrisma] in this verse within a Jewish-Christian setting, as a reference to the gift of the Spirit, which is 'the characteristic endowment' of believers (Westcott, 73). Paul seems also to be (independently ) indebted to this kind of interpretation when he speaks of God in Christ 'anointing' the believer, and putting his Spirit in our hearts 'as a deposit, guaranteeing what is to come' (2 Cor 1:21-22)" (Stephen S. Smalley, 1, 2, 3 John [Word Biblical Commentary 51; Waco: Word, 1984], 106).
} 
If the world hates you, know that it has hated me before it hated you. If you were of the world, the world would love you as its own; but because you are not of the world, but I chose you out of the world, therefore the world hates you. (15:18-19 ESV)

In fact, Jesus insisted that even his disciples were spiritually impotent without Him: "for apart from me you can do nothing" (15:5 ESV). Thus by a fortiori, from the greater to the lesser, if even believers are unable to have a relationship with God without Christ, how much more this must be true of the world of unbelievers. This dire reality of the world without the Spirit of truth is exacerbated by the noetic effects of $\sin$ that flow from the spiritual realm of the darkness of mankind's lost estate. ${ }^{96}$ Thus John's Gospel preserves Jesus' verdict against those who claimed that their spiritual father was Abraham, the patriarch of Israel:

Why do you not understand what I say? It is because you cannot bear to hear my word. You are of your father devil, and your will is to do your father's desires. He was a murderer from the beginning, and does not stand in the truth, because there is no truth in him. When he lies, he speaks out of his own character, for he is a liar and the father of lies. But because I tell the truth, you do not believe me. (8:43-46 ESV)

This revealing work of the Spirit, moreover, comports with the very nature of John's Gospel as a written revelation of God. Thus scholars of Johannine literature have identified four general approaches to how revelation of the knowledge of God is imparted by the Fourth

\footnotetext{
96 See, for example, Peter A. Lillback, "The Significance of the Noetic Effects of Sin for a Theistic Epistemology" (Th.M. thesis, Dallas Theological Seminary, 1978).
} 
Gospel. Gail R. O’Day explains,

This overview of four different approaches to revelation in the Fourth Gospel shows the variety of answers that can be given to the question, "How is God known?" and shows the link between the answer to that question and the interpretive framework through which one views the Gospel of John.

1. In the first approach, which answers that God is known in the content of Scripture, the Fourth Gospel is a source for lessons and examples about Jesus and God.

2. In the comparative approach to revelation, which answers that God is known through mythical paradigms contained in Scripture, the Fourth Gospel is an articulation of shared mythical language and paradigms.

3. In the existential approach, which answers that God is known in the existential moment of personal decision called forth by Scripture, the Fourth Gospel is the vehicle that facilitates the subjective experience of God.

4. Finally, in the dogmatic approach, which answers that God is known in dogmatic reflection on the identity of Jesus, the Fourth Gospel is an articulation of Christological dogma. ${ }^{97}$

While each of these summarized approaches is distinct and some are mutually exclusive, together they underscore, however, that John's Gospel requires revelation for God to be known. This Johannine insistence militates against an apologetic that appeals to reason without or at the expense of the primacy of Scripture.

97 Gail R. O'Day, Revelation in the Fourth Gospel: Narrative Mode and Theological Claim (Philadelphia: Fortress, 1986), 43-44. 


\section{Conclusion}

Thus in a proleptic sense, Johannine theology is the Reformed theology of Calvin. ${ }^{98}$ John seems to resonate with Calvin when he declares, "Let this point therefore stand: that those whom the Holy Spirit has inwardly taught truly rest upon Scripture, and that Scripture indeed is self-authenticated" (Calvin, Institutes 1.8.5; Battles 1:80). John's teachings appear to comport with Van Til's apologetics given its emphasis on the blindness of man, and the necessity of faith before reason. That John used evidences after faith reflects the apologetic approach of an Augustinian, rather than the mystic variety of presuppositionalism reflected by Tertullian's extreme fideism. And decisively, in the author's opinion at least, it prevents any claim by Thomism for even a modicum of support in Johannine thought. The relationship between faith and reason presented by Johannine

\footnotetext{
98 In Calvin's mind, man's search for truth is vain, for he cannot establish the proper priorities for determining which area of the world to investigate.

Yet this longing for truth, such as it is, languishes before it enters upon its race because it soon falls into vanity.... Then it grievously labors under another sort of vanity: often it cannot discern those things which it ought to exert itself to know. For this reason, in investigating empty and worthless things, it torments itself in its absurd curiosity, while it carelessly pays little or no attention to matters that it should particularly understand. Indeed, it scarcely ever seriously applies itself to the study of them.... Solomon, through the whole of his Ecclesiastes, after recounting all those studies in which men seem to themselves to be very wise, declares them to be vain and trifling [chps. 1:2, 14; 2:11; etc.]. (Calvin, Institutes 2.2.12; Battles 1:271) Moreover, Calvin claims that this understanding of Spiritual truth is only the result of divine election.

Let us, then, know that the only true faith is that which the Spirit of God seals in our hearts. Indeed, the modest and teachable reader will be content with this one reason: Isaiah promised all the children of the renewed church that "they would be God's disciples" [Isa. 54:13]. God deems worthy of singular privilege only his elect, whom he distinguishes from the human race as a whole ... Whenever, then, the fewness of believers disturbs us, let the converse come to mind, that only those to whom it is given can comprehend the mysteries of God [cf. Matt. 13:11]. (Calvin, Institutes 1.8.5; Battles 1:81)
} 
theology is a remarkable biblical affirmation of the leading themes of presuppositional apologetics. 